\title{
FIRST RECORDS OF SINANODONTA WOODIANA (LEA, 1834) AND CORBICULA FLUMINEA (O. F. MÜLLER, 1774) (MOLLUSCA, BIVALVIA) FROM THE ADRIATIC PART OF CROATIA
}

\author{
LUBOŠ BERAN
}

\begin{abstract}
Nature Conservation Agency of the Czech Republic, Regional Office Kokořínsko - Máchův kraj Protected Landscape Area Administration, Česká 149, CZ-27601 Mělnik, Czech Republic (e-mail: lubos.beran@nature.cz); (1) https://orcid.org/0000-0002-5851-6048

ABSTRACT: Sinanodonta woodiana (Lea) and Corbicula fluminea (O. F. Müller) are among the most invasive aquatic molluscs found in Europe. Both species were recorded in the Adriatic part of Croatia for the first time in 2019 although in the Danubian Croatia they were more common. An abundant population of S. woodiana was found in an oxbow of the Cetina River; mussels with shell length of ca. 12-17 cm dominated. A population of $C$. fluminea was recorded in the freshwater section of the Zrmanja River above the Jankovića Buk waterfall which forms the border between the brackish and the freshwater sections of the river. Possible pathways of their introduction and reasons for their rare occurrence in contrast to the Danubian Croatia are discussed.
\end{abstract}

KEY WORDS: non-native species; Chinese mussel; Asian clam; introduction; range expansion

\section{INTRODUCTION}

For the last few decades spread of non-native species has been one of the major threats to aquatic ecosystems (ABRAMOVITZ 1996). Most of the natural barriers for species dispersal have been weakened by human activities (LEPPÄKOSKI et al. 1991, 2002), thus allowing a long distance range expansion of many non-native species. In many areas dispersal of non-native species is one of the main reasons for biodiversity loss. Being easily transported by humans and often having a significant impact on native faunas and ecosystems, freshwater molluscs form an important group of non-native species (MEIERBROOK 2002). A notable increase in the occurrence of non-native freshwater molluscs has been observed in the last decades (e.g. CiANFANELLI et al. 2007, LORENCOVÁ et al. 2015). Recently, Sinanodonta woodiana (Lea, 1834) and Corbicula fluminea (O. F. Müller, 1774) have been spreading rapidly. S. woodiana is known to occur in many localities in the Danube River basin in Croatia (LAJTNER \& CRNČAN 2011, BERAN 2013, PETRAVIĆ et al. 2019, author's unpub- lished data). According to KONEČNÝ et al. (2018) western Romania, southern Hungary and northern Croatia are one of the two probable source areas for European populations of $S$. woodiana. The species is common in Serbia (PAUNOvić et al. 2006, 2008) and occurs in eastern Slovenia (GovedIČ 2017). In the Adriatic Sea basin it is known from many sites in Italy (CIANFANELLI at al. 2007, Cilenti et al. 2019) and was also found in Montenegro (TOMOVIĆ et al. 2013). On the other hand, there were no previous records of the Chinese pond mussel from the Adriatic part of Croatia. Finding its empty shells on the shores of Lake Vrana was an exception, and later detailed research failed to confirm its occurrence in the lake (LAJTNER \& CRNČAN 2011, BERAN et al. 2013). According to LAJTNER \& CRNČAN (2011), the records of empty shells of $S$. woodiana were the consequence of transport of live individuals from continental parts of Croatia as fishing bait, since Lake Vrana is known for its rich fish fauna and is an important destination for anglers from continental Croatia, particularly during 
the summer vacation period. It can be assumed that any live bivalves that may have been released into the lake probably did not survive, due to stress caused by increased salinity, as the lake is connected to the sea by a manmade channel (LAJTNER \& CRNČAN 2011).

C. fluminea is native in southeastern Asia which includes southeast China, Korea and southeast Russia (ZHADIN 1952, MORTON 1986). Currently, the species is widely distributed, and its range includes also other parts of Asia, North and South America, Europe, Africa and Australia (MORTON 1986, ARAUjO et al. 1993, CRESPO et al. 2015, PONDER et al. 2016). C. fluminea can colonise fresh waters, as well as brackish estuaries with salinities of up to 17 PSU (LUCY et al. 2012). It was very often introduced into estuaries of large rivers with ballast water, due to increased international trade (KARATAYEV et al. 2007); it was probably brought to North America in the 1930s by Asian immigrants as a food source (BRITTON \& MORTON 1979). Once introduced to a new catchment area, its

\section{MATERIAL AND METHODS}

The data were obtained during routine field surveys conducted in 2019 and confirmed in 2020. The main method was washing vegetation or sediments on a metal sieve (20 cm diameter, $0.8 \mathrm{~mm}$ mesh) combined with hand-collecting from the surface of stones, wood and artificial materials (e.g. plastic bags and bottles), and snorkelling in shallow parts (up to ca. $3 \mathrm{~m}$ deep). In the site where $C$. fluminea was discovered in 2019, the sediment from an area of $1 \mathrm{~m}^{2}$ spread is limited by environmental factors and facilitated by transport for food and aquaculture, shipping, fish stocking, angling and deliberate introduction (for review see MCMAHON 1982, 1999, KARATAYEV et al. 2007).

C. fluminea is regarded as one of the most important non-native invasive species in aquatic ecosystems, mainly due to its wide distribution and ecological and economic impacts (CRESPO et al. 2015).

The first record of $C$. fluminea in Croatia dates from 2001 when the species was recorded in the Danube River (PAUnOvić et al. 2007, LAJTNER et al. 2016) and later also in the rivers Sava, Drava, Una and Kupa in the Danube River catchment area (PAUNOvić et al. 2007, LAJTNER et al. 2016, ĆUK et al. 2019, author's unpublished data). No record of the Asian clam existed from the Adriatic part of Croatia, though in the Adriatic Sea basin it was known from many localities in northern Italy (CIANFANELLI et al. 2007).

was removed and sieved in 2020. The collected individuals were measured (length) and stored in $80 \%$ ethanol. A shallow place with abundant occurrence of $S$. woodiana was chosen in 2020. Individuals from this plot $\left(10 \mathrm{~m}^{2}\right)$ were collected by hand (without removing and sieving the sediment) and measured (length, height, width). Selected shells of S. woodiana and alcohol-preserved specimens of $C$. fluminea are deposited in the author's collection.

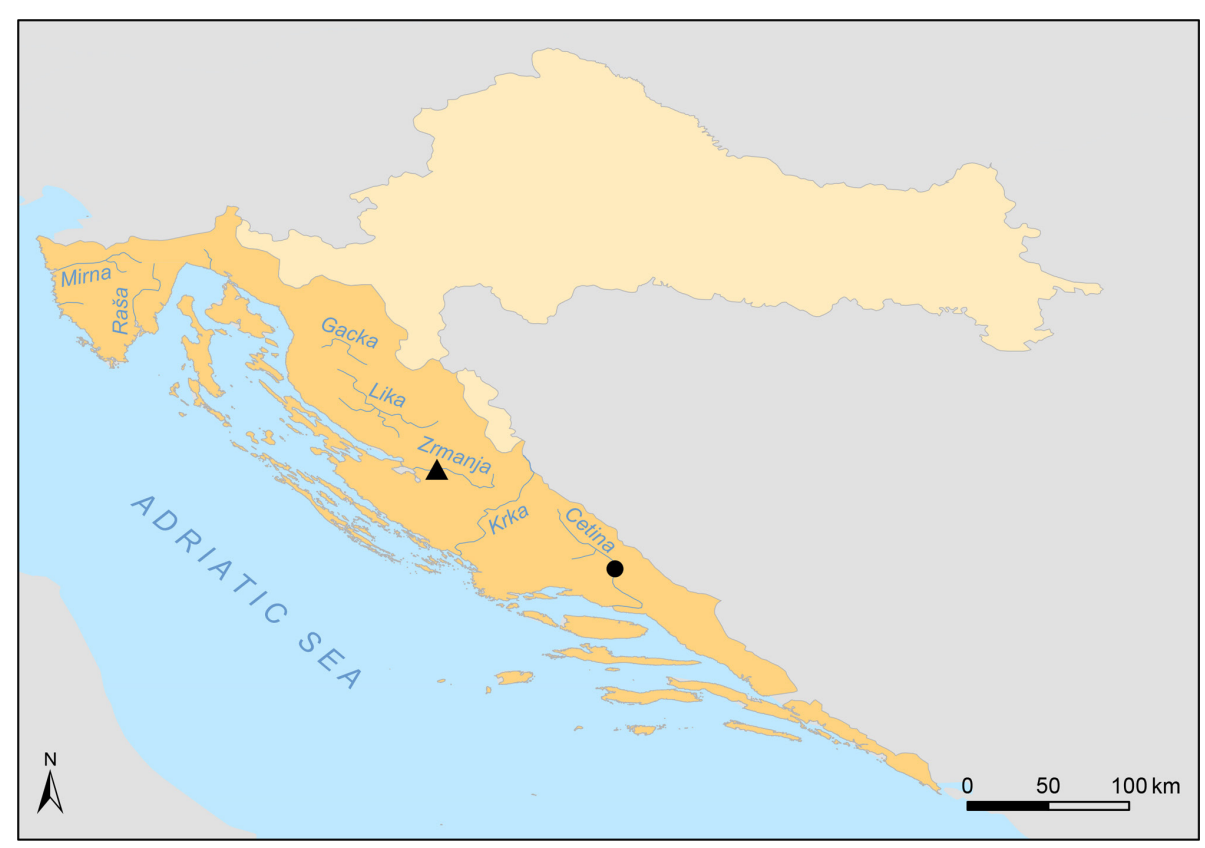

Fig. 1. Records of Sinanodonta woodiana and Corbicula fluminea in the Adriatic part (dark yellow) of Croatia. Circle Sinanodonta woodiana, triangle - Corbicula fluminea. Drawing H. MEDKOVÁ 


\section{RESULTS}

Both species were found during faunistic research in 2019 in the Adriatic part of Croatia. S. woodiana was recorded in an old oxbow of the Cetina River near Trilj $\left(43^{\circ} 38.95^{\prime} \mathrm{N}, 16^{\circ} 42.88^{\prime} \mathrm{E}, 21.08 .2019\right.$, Figs $1-3)$. Its population was abundant, with the density estimated at 2-5 individuals $/ \mathrm{m}^{2}$. Most mussels occurred at the depth of $100-150 \mathrm{~cm}$. The occurrence was confirmed one year later (16.08.2020). The water level was ca. $50 \mathrm{~cm}$ lower than in 2019. Altogether 33 mussels were found within $10 \mathrm{~m}^{2}$ at the depth of ca. $60 \mathrm{~cm}$; individuals of shell length of ca. 12-17 $\mathrm{cm}$ dominated (Fig. 4). The oxbow is not connected to the Cetina River and the water is significantly warmer than in the river. The oxbow is an important angling site and several information boards with instructions for anglers are situated along its banks. No other unionids were found in the oxbow or in the main channel of the Cetina River during a thorough search conducted between 2018 and 2020 at more than 10 sites (author's unpublished data).

The molluscan communities of the Zrmanja and Krupa rivers have been studied since 2009 (BERAN
2011, author's unpublished data). C. fluminea was found in 2019 (11.07.2019) at the Zrmanja River, ca. $70 \mathrm{~m}$ above the Jankovića Buk waterfall $\left(44^{\circ} 12.18^{\prime} \mathrm{N}\right.$,

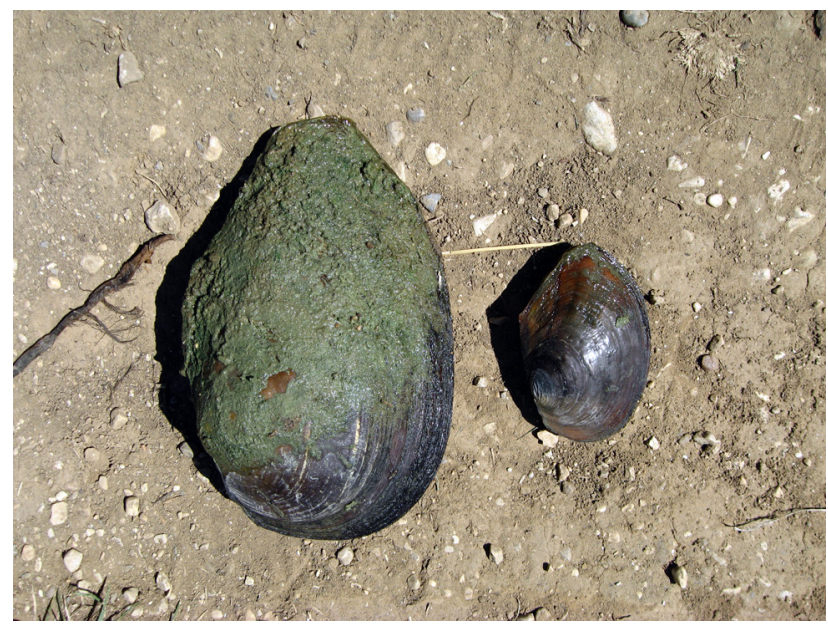

Fig. 2. Sinanodonta woodiana from the oxbow of the Cetina River. The biggest and smallest collected individuals. Photo: L. BERAN

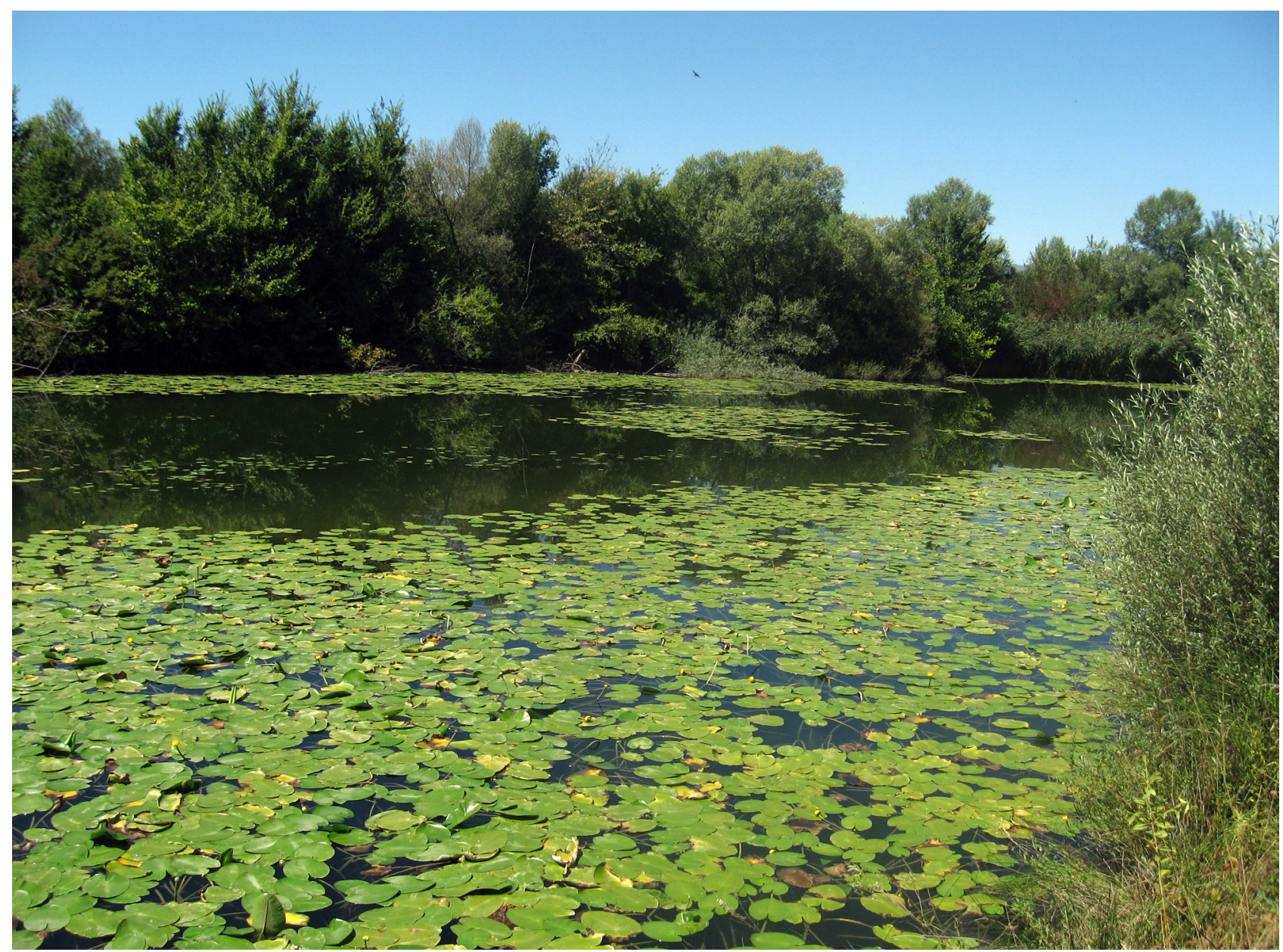

Fig. 3. The oxbow of the Cetina River in 2019 (the water level was ca. $50 \mathrm{~cm}$ lower in 2020). Photo: L. BERAN 


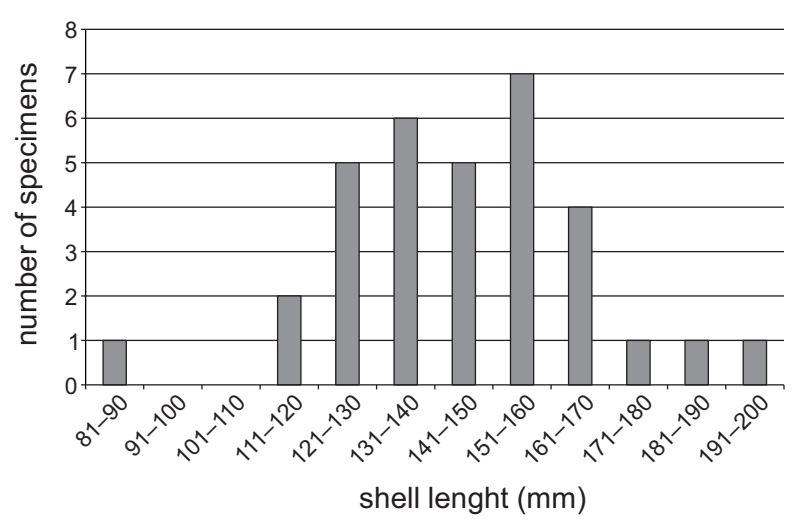

Fig. 4. Shell length of individuals of S. woodiana collected from $10 \mathrm{~m}^{2}$

$15^{\circ} 43.32$ 'E, Figs $\left.1,5,6\right)$. The waterfall, ca. $4 \mathrm{~m}$ high, forms the border between the brackish and the freshwater sections of the river. Only two young individuals (less than $10 \mathrm{~mm}$ ) were found during the routine faunistic survey. The occurrence was confirmed one year later (05.07.2020). C. fluminea was recorded in the sediment in a ca. $80 \mathrm{~m}$ long shallow section above the waterfall (see Fig. 6); the occurrence of live individuals was scattered except the place where C. fluminea was found in 2019. Altogether 42 specimens were collected from the sediment within an area of $1 \mathrm{~m}^{2}$ at the depth of $50-70 \mathrm{~cm}$, near the river bank. Smaller specimens dominated (Fig. 5). The largest shell was only $16.2 \mathrm{~mm}$ in length while the smallest specimen was $3.9 \mathrm{~mm}$ long. No empty shells were found in 2019 or 2020 . Five other species (Unio

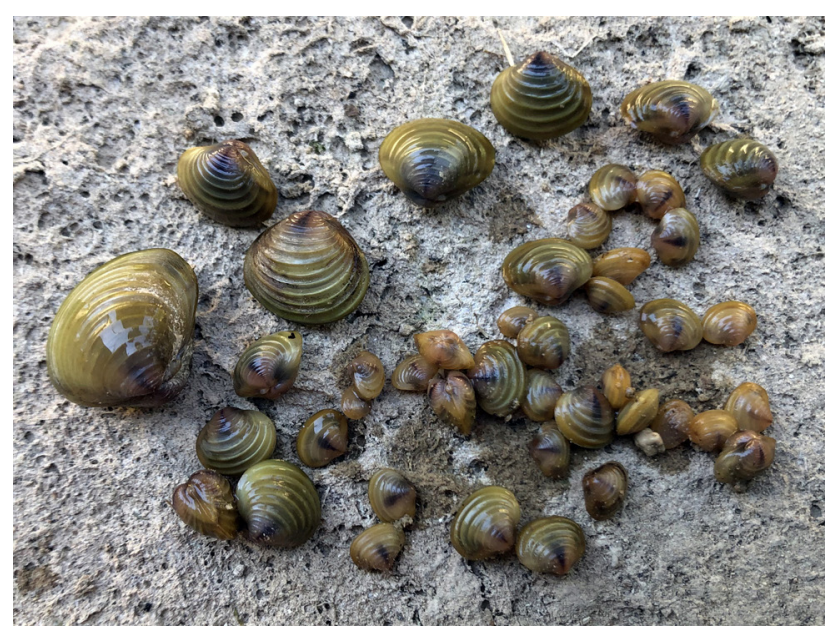

Fig. 5. Individuals of $C$. fluminea collected from $1 \mathrm{~m}^{2}$. Length of the biggest specimen $16.2 \mathrm{~mm}$, length of the smallest specimen $3.9 \mathrm{~mm}$. Photo: L. BERAN

elongatulus, Anodonta exulcerata, Pisidium amnicum, $P$. nitidum, $P$. subtruncatum) co-occurred. The same site was visited in 2013 and 2015 and C. fluminea was not found. Above this short section the Zrmanja River is only slow-flowing and deeper, and C. fluminea had not been found there. It was not observed below the waterfall, in the brackish section where salinity varies from 2 PSU on the surface to 36 PSU at the bottom (FIKET et al. 2018). The species was not found in any other studied locality in the brackish or freshwater sections of the river (author's unpublished data, more than 20 localities between 2009 and 2020).

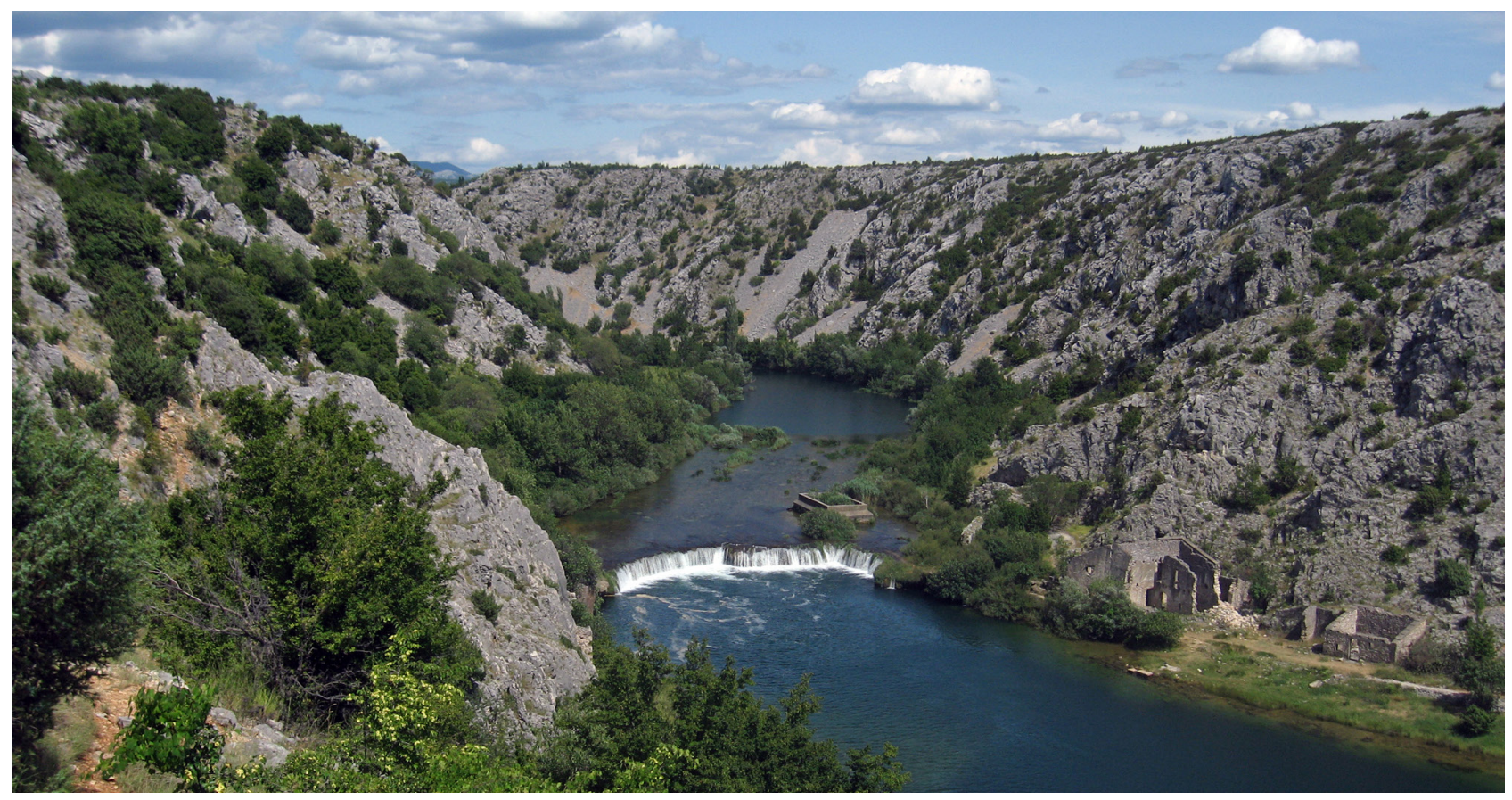

Fig. 6. The Zrmanja River at Jankovića Buk waterfall. Photo: L. BERAN 


\section{DISCUSSION}

Sinanodonta woodiana was probably introduced to Europe with glochidia-infected Asian carps (KONEČNÝ et al. 2018). Its larvae successfully parasitise a wide spectrum of European fish species (DOUDA et al. 2012, HUBER \& GEIST 2019) and develop more successfully than those of the native Anodonta species (HUBER \& GEIST 2019). In the case of the oxbow of the Cetina River it is very likely that $S$. woodiana was introduced with infected fish. The population was abundant (at least hundreds of individuals), the largest mussel was $194 \mathrm{~mm}$ in length, so it is probable that $S$. woodiana was introduced more than 10 years ago. The oxbow is used by anglers, the species composition of its fish fauna differs from that in the river and it is likely that most of the fish have been introduced by anglers. It cannot be excluded that anglers from continental Croatia bring them as live bait and some of them survive. This possibility is invoked by LAJTNER \& CRNČAN (2011) to explain finding of empty shells of $S$. woodiana on the shores of Lake Vrana (see Introduction). The diverse and abundant fish fauna combined with warmer stagnant water offers optimal conditions for development of the dense mussel population in contrast to the fast-flowing and colder main channel of the Cetina River with its smaller fish density. Although the population was abundant, no individuals smaller than $80 \mathrm{~mm}$ were recorded. The causes are not well known. In the case of the smallest individuals living in the sediment, the reason may be the fact that the sediment was not sieved. However, no individuals with shell length of less than $80 \mathrm{~mm}$ were documented. They may have occurred in other parts of the oxbow and were overlooked, or the reproduction was irregular. C. fluminea was found in the Zrmanja River above the Jankovića Buk waterfall. Because the species was not observed there during the previous visits in 2013 and 2015, no empty shells were found, and only small individuals were recorded, the invasion was probably detected in its early stage. The way of introduction remains unclear. The nearest known localities are situated in the Danube River basin, ca. 120-150 km away. The species was found only above the Jankovića Buk waterfall which forms the border between the brackish and the freshwater sections of the river and presents a barrier to dispersal. Except the Razovac reservoir, the river is not very popular for angling, the recreational cruises operate only in the brackish section, and C. fluminea was not found anywhere else, either in the freshwater or the brackish sections. An unintentional introduction, for example by tourists or divers, can be considered; the introduction may have been caused by birds, but the river is not an important route for bird migrations.
Abiotic factors in the freshwater section (ŠTAMBUK-GILJANOVIĆ 2003) correspond with the environmental limits mentioned in LUCY et al. (2012) and there are probably no barriers to further upstream expansion of this species. It can be assumed that $C$. fluminea can gradually overcome the barriers formed by the Razovac reservoir and waterfalls and its natural spread might be facilitated by local human activities (kayaking, rafting, angling, diving and other forms of recreation). The reason for its absence in the brackish section may be the high salinity at the bottom of the Zrmanja River (25-36 PSU) (FIKET et al. 2018) while the limit for the species is ca. 17 PSU (LUCY et al. 2012).

Croatian rivers and lakes in the Adriatic Sea basin are inhabited by diverse communities of aquatic molluscs with many endemic or endangered species (e.g. BERAN 2011, 2016, 2017, Froufe et al. 2017). The invasion of $S$. woodiana and C. fluminea may cause negative changes in these communities.

S. woodiana can compete with the native unionids for food, increase resistance to glochidia in their potential fish hosts and serve as vector for introduction of new parasites and diseases (DONROVICH et al. 2017, LOPES-LiMA et al. 2017, DOUDA \& ČADKOVÁ 2018). Compared to the native Anodonta species glochidia develop more successfully, metamorphose faster and these traits, together with faster growth and greater fecundity of $S$. woodiana, are likely to contribute to a competitive advantage over the native anodontines (HUBER \& GEIST 2019). The spread of this species to rivers inhabited by autochthonous species would have a negative impact on their populations. S. woodiana has so far been found in only one oxbow of the Cetina River. No other unionids were detected in this oxbow and in the main channel of the Cetina River while other rivers (e.g. Zrmanja, Krka, Neretva) hold abundant unionid populations (BERAN 2011, 2016, FroufE et al. 2017, author's unpublished data, LOPES-LIMA pers. comm.). For this reason it is important to avoid further spread of the Chinese mussel outside the existing locality. It is necessary to inform anglers about the occurrence of this species, for example in the form of information boards. Transfer of fish from the locality should be excluded, as well as transfer of $S$. woodiana (e.g. as live bait). The population of $S$. woodiana is now confined to the isolated oxbow but the possibilities of reducing it are limited. Methods of controlling the mussel are mentioned by DoudA et al. (2016). Only regular collection of the mussels could be used in this case. However, it would only lead to a reduction of the species' abundance and not to its complete eradication. 
C. fluminea is regarded as a non-native species which may endanger the native fauna or natural habitats (CEBULSKA \& KRODKIEWSKA 2019, HAAG 2019). Due to its rapid growth, competition for food, earlier sexual maturity, short life span and high fecundity it may present a threat to other bivalves (SOUSA et al. 2008). On the other hand, the genus Corbicula is known from interglacial deposits of Europe (LOŽEK 1964, MeIjer \& PREeCE 2000) and is among the best-known interglacial molluscs in the Pannonian Plain (PAUNOVIĆ et al. 2007). These facts raise a question whether to consider the recent invasion of Corbicula in Europe as an introduction or as a natural reintroduction, albeit accelerated by human activities (PAUnOvić et al. 2007). The molluscs of rivers and other freshwater (or brackish in the case of $C$. fluminea) habitats suitable for both species in the Adriatic part of Croatia have been intensively studied for more than a decade. Since 2009 I have visited more than 50 localities in the rivers Cetina, Krka, Krupa, Mirna, Neretva, Ričica and Zrmanja, lakes near Baćina and Lake Vrana (e.g. BERAN 2011, 2016, unpublished data, BERAN et al. 2013). Other scientists have also paid attention to freshwater molluscs of the area (LAJTNER \& CRNČAN 2011, VUČKOVIĆ 2013). Nevertheless, these species have so far been found in only one locality each, while in the Danube River basin they are already common (PAUNOVIĆ et al. 2007, LAJTNER \& CRNČAN 2011, BERAN 2013,
LAJTNER et al. 2016, ĆUK et al. 2019, Petravić et al. 2019, author's unpublished data). In the case of C. fluminea the probable reason is the fact that the species is very often introduced to new catchment areas with ballast water of big ships (e.g. KARATAYEV et al. 2007). However, the rivers in the Adriatic part of Croatia are short and with low flow, so the ships do not use their estuaries.

S. woodiana is mainly introduced with glochidia-infected fish (e.g. KONEČNÝ et al. 2018), and the introduction is facilitated by the wide spectrum of host species for glochidia in Europe (DOUDA et al. 2012, HUBER \& GEIST 2019). In the Adriatic part there are much fewer waterbodies suitable for fish farming or intensive angling in comparison with the Danubian Croatia. These are the probable reasons why neither of the two species has become widespread yet in the Adriatic part of Croatia.

Due to the possible negative impact on the native mollusc communities it is advisable to monitor further spread of the two non-native species in the Adriatic part of Croatia.

\section{ACKNOWLEDGEMENTS}

I would like to thank HeLENA MEDKOVÁ for drawing the map, VERONIKA HAMILTON for the language corrections and the anonymous reviewers for their valuable comments.

\section{REFERENCES}

ABRAMOVITZ J. 1996. Imperiled waters, impoverished future: The decline of freshwater ecosystems. Worldwatch Paper No. 128, Worldwatch Institute, Washington, D.C.

Araujo R., Moreno D., Ramos M. A. 1993. The Asiatic clam Corbicula fluminea (Müller, 1774) (Bivalvia: Corbiculidae) in Europe. American Malacological Bulletin 10: 39-49.

BERAN L. 2011. Non-marine molluscs (Mollusca: Gastropoda, Bivalvia) of the Zrmanja River and its tributaries (Croatia). Natura Croatica 20: 397-409.

BERAN L. 2013. Aquatic molluscan fauna (Mollusca) of the Korana River (Croatia). Natura Croatica 22: 223-234.

BERAN L. 2016. A contribution to knowledge of freshwater molluscs (Mollusca) of the Krka River in the Krka National Park (Croatia). Natura Croatica 25: 295-304. https://doi.org/10.20302/NC.2016.25.25

BERAN L. 2017. Notes on the distribution and status of Tanousia zrmanjae (Brusina, 1866) (Gastropoda: Truncatelloidea: Hydrobiidae). Folia Malacologica 25: 109-115. https://doi.org/10.12657/folmal.025.006

BERAN L., LAJTNER J., CRNČAN P. 2013. Aquatic molluscan fauna (Mollusca: Gastropoda, Bivalvia) of Vrana Lake Nature Park (Croatia). Natura Croatica 22: 15-27.
BRITTON J. C., MORTON B. 1979. Corbicula in North America: The evidence reviewed and evaluated. In: BRITTON J. C. (ed.). Proccedings of the First International Corbicula Symposium 1977. Christian University, Texas: pp. 250-287.

Cebulska K. D., KrodKIEWSKA M. 2019. Further dispersion of the invasive alien species Corbicula fluminea (O. F. Müller, 1774) in the Oder River. Knowledge \& Management of Aquatic Ecosystems 420: 14. https:// doi.org/10.1051/kmae/2019008

CIANFANELLI S., LORI E., BODON M. 2007. Non-indigenous freshwater molluscs and their distribution in Italy. In: GHERARDI F. (ed.). Biological invaders in inland waters: Profiles, distribution and threats. Springer, Dordrecht, pp. 103-121. https://doi.org/10.1007/978-1-40206029-8_5

Cilenti L., Mancinelli G., Scirocco T., Specchiulli A. 2019. First record of Sinanodonta woodiana (Lea, 1834) in an artificial reservoir in the Molise region, Southeast Italy. Bioinvasions Records 8: 320-338. https://doi. org/10.3391/bir.2019.8.2.14

Crespo D., DOlbeth M., Leston S., SOUSA R., PARdAL M. Â. 2015. Distribution of Corbicula fluminea (Müller, 1774) in the invaded range: a geographic approach with notes on species traits variability. Biological Invasions 
17: 2087-2101. https://doi.org/10.1007/s10530-0150862-y

ĆUK R., MiLIŠA M., ATANACKOVIĆ A., DEKIĆ S., BLAŽEKOVIĆ L., ŽGANEC K. 2019. Biocontamination of benthic macroinvertebrate assemblages in Croatian major eivers and effects on ecological quality assessment. Knowledge \& Management of Aquatic Ecosystems 420, 11. https://doi.org/10.1051/kmae/2019003

DONROVICH S. W., DOUDA K., PLECHINGEROVÁ V., RYLKOVÁ K., HORKÝ P., SLAVÍK O., LIU H. Z., REICHARD M., LOPES-LIMA M., SOUSA R. 2017. Invasive Chinese pond mussel Sinanodonta woodiana threatens native mussel reproduction by inducing cross-resistance of host fish. Aquatic Conservation Marine and Freshwater Ecosystems 27: 1325-1333. https://doi.org/10.1002/ aqc. 2759

DOUDA K., ČADKOVÁ Z. 2018. Water clearance efficiency indicates potential filter-feeding interactions between invasive Sinanodonta woodiana and native freshwater mussels. Biological Invasions 20: 1093-1098. https:// doi.org/10.1007/s10530-017-1615-X

DOUdA K., Kalous L., HORKÝ P., Slavík O., VelíšEK J., KOLÁŘOVÁ J. 2016. Metodika eliminace a prevence šíření invazního druhu škeblice asijská (Sinanodonta woodiana) ve vodních ekosystémech a akvakulturních zařízeních ČR. Česká zemědělská univerzita v Praze.

DOUdA K., VRTíleK M., SLAVÍK O., REICHARD M. 2012. The role of host specificity in explaining the invasion success of the freshwater mussel Anodonta woodiana in Europe. Biological Invasions 14: 127-137. https://doi. org/10.1007/s10530-011-9989-7

FIKET Ž., IVANIĆ M., TURK M. F., MIKAC N., KNIEWALD G. 2018. Distribution of trace elements in waters of the Zrmanja River Estuary (Eastern Adriatic Coast, Croatia). Croatica Chemica Acta 91: 29-41. https://doi. org/10.5562/cca3202

Froufe E., LOPES-LIMA M., RicCARdi N., ZACCARA S., VANETTI I., LAJTNER J., TEXEIRA A., VARANDAS S., PRIÉ V., ZIERITZ A., SOUSA R., BOGAN A. E. 2017. Lifting the curtain on the freshwater mussel diversity of the Italian Peninsula and Croatian Adriatic coast. Biodiversity and Conservation 26: 3255-3274. https://doi.org/10.1007/ s10531-017-1403-z

GoVEDIČ M. 2017. Velike školjke celinskih voda Slovenije: razširjenost, ekologija, varstvo. Center za kartografijo favne in flore, Miklavž na Dravskem polju.

HAAG W. 2019. Reassessing enigmatic mussel declines in the United States. Freshwater Mollusk Biology and Conservation 22: 43-60. https://doi.org/10.31931/ fmbc.v22i2.2019.43-60

Huber V., Geist J. 2019. Reproduction success of the invasive Sinanodonta woodiana (Lea 1834) in relation to native mussel species. Biological Invasions 21: 34513465. https://doi.org/10.1007/s10530-019-02060-3

KaratayeV A. Y., PADilla D. K., Minchin D., BOlTOVSKoY D., BuRlaKovA L. E. 2007. Changes in global economies and trade: the potential spread of exotic freshwater bivalves. Biological Invasions 9: 161-180. https:// doi.org/10.1007/s10530-006-9013-9
KONEČNÝ A., POPA O. P., BARTÁKOVÁ V., DOUDA K., BRYJA J., SMITH C., POPA L. O., REICHARD M. 2018. Modelling the invasion history of Sinanodonta woodiana in Europe: Tracking the routes of a sedentary aquatic invader with mobile parasitic larvae. Evolutionary Applications 11: 1975-1989. https://doi.org/10.1111/eva.12700

LAJTNER J., CRNČAN P. 2011. Distribution of the invasive bivalve Sinanodonta woodiana (Lea, 1834) in Croatia. Aquatic Invasions 6: 119-124. https://doi.org/10.3391/ ai.2011.6.S1.027

LAJTNER J., CRNČAN P., ĆUK R., DEKIĆ S., GOTTSTEIN S., Hudina S., Kovačević S., Lucić A., PAUnOvić M., Simić V., TOMOVIĆ J., ŽGANEC K. 2016. Distribution of the invasive alien bivalve Corbicula fluminea (Müller, 1774) in Croatia. Abstracts, 2nd Croatian Symposium on invasive species with International Participation, Zagreb, 21-22.11.2016: 57.

LEPPÄKOSKI E., GOLlASCH S., OLENIN S. 2002. Invasive aquatic species of Europe: distribution, impacts and management. Kluwer Academic Publishers, Dordrecht. https://doi.org/10.1007/978-94-015-9956-6

LEPPÄKOSKI E., MiKolasch A., PUKAll R., SCHUMANN P., KÖSTER M., SCHAUER F. 1991. Introduced species - resource or threat in brackish-water seas? Examples from the Baltic and the Black Sea. Marine Pollution Bulletin 23: 219-223. https://doi.org/10.1016/0025326X(91)90678-L

Lopes-Lima M., Sousa R., Geist J., Aldridge D. C., ARAujo R., BERgENGREN J., BESPALAYA Y., BóDis E., BURLAKOVA L., VAN DAMME D., DOUDA K., FroufE E., GeOrgIEV D., GuMPINGER C., KARATAYEV A., KebAPÇI Ü., KILlEEN I., LAJTNER J., LARSEN B. M., LAUCERI R., LEgAKIS A., LOIS S., LUNDBERG S., MOORKENS E., Motte G., Nagel K.-O., Ondina P., Outeiro A., PAUNOVIĆ M., PRIÉ V., VON PROSCHWITZ T., RICCARDI N., Rudzīte M., Rudzītis M., SCHEDER C., SEDDON M., ȘEREFLIȘAN H., Simić V., SOKOlOVA S., STOECKL K., TASKINEN J., TeIXeIRA A., THIELEN F., TRIChKova T., VARANDAS S., ViCENTINI H., ZAJĄC K., ZajĄC T., ZOGARIS S. 2017. Conservation status of freshwater mussels in Europe: state of the art and future challenges. Biological Reviews 92: 572-607. https://doi. org/10.1111/brv.12244

LORENCOVÁ E., BERAN L., HORSÁKOVÁ V., HORSÁK M. 2015. Invasion of freshwater molluscs in the Czech Republic: time course and environmental predictors. Malacologia 59: 105-120. https://doi.org/10.4002/040.059.0107

LOŽEK V. 1964. Quartärmollusken der Tschechoslowakei. Rozpravy Ústředního ústavu geologického 31: 1-374.

LuCy F. E., KaratayeV A. Y., Burlakova L. E. 2012. Predictions for the spread, population density, and impacts of Corbicula fluminea in Ireland. Aquatic Invasions 7: 465-474. https://doi.org/10.3391/ai.2012.7.4.003

MCMAHON R. F. 1982. The occurrence and spread of the introduced Asiatic freshwater clam, Corbicula fluminea (Müller), in North-America - 1924-1982. Nautilus 96: 134-141.

MCMAHON R. F. 1999. Invasive characteristics of the freshwater bivalve Corbicula fluminea. In: CLAUDI R., LEACH J. H. (eds). Nonindigenous freshwater organisms. 
Vectors, biology, and impacts. Lewis Publishers, Boca Raton, pp. 315-343.

MEIER-BROOK C. 2002. What makes an aquatic ecosystem susceptible to mollusk invasion? In: FALKNER M., GroH K., Speight M. C. D. (eds). Collectanea Malacologica, Festschrift für Gerhard Falkner. ConchBooks, Hackenheim, pp. 405-415.

Meijer T., Preece R. C. 2000. A review of the occurrence of Corbicula in Pleistocene of North-West Europe. Geologie en Mijnbouw/Netherlands Journal of Geosciences 79: 241-255. https://doi.org/10.1017/ S0016774600021739

MORTON B. 1986. Corbicula in Asia - an updated synthesis. American Malacological Bulletin, Special Edition: 113-124.

Paunović M., CsÁnyi B., Simić V., Stojanović B., CAKić P. 2006. Distribution of Anodonta (Sinanodonta) woodiana (Lea, 1834) in inland waters of Serbia. Aquatic Invasions 1: 154-160. https://doi.org/10.3391/ ai.2006.1.3.10

PAUNOVIĆ M., CSÁNYI B., KNEŽEVIĆ S., SiMIĆ V., NENADIĆ D., JANKOVČEV-TODOROVIĆ D., STOJANOVIĆ B., CAKIĆ P. 2007. Distribution of Asian clams Corbicula fluminea (Müller, 1774) and C. fluminalis (Müller, 1774) in Serbia. Aquatic Invasions 2: 99-106. https://doi.org/10.3391/ ai.2007.2.2.3

PAUnOVIĆ M., BORKOVIĆ S., PAVlOVIĆ S., SAIČIĆ Z., CAKIĆ P. 2008. Results of the 2006 Sava survey - Aquatic macroinvertebrates. Archives of Biological Sciences 60: 265-271. https://doi.org/10.2298/ABS0802265P

PETRAVIĆ J., JARNJAK M., ANDRAŠIĆ M., KURI K., JAKŠIĆ G., JAJČEVIĆ H., DERGEZ M., LAJTNER J. 2019. Distribution and population structure of the Unionidae family in the Kupa River in Karlovac County. 54th Croatian \& 14th
International Symposium on Agriculture, February 17 22, Vodice: 395-399.

Ponder W. F., Hallan A., Shea M. E., Clark S. A., Richards K., KLUNZINGER M. W., KESSNER V. 2020. Australian freshwater molluscs. Revision 1. Available online at https://keys.lucidcentral.org/keys/v3/freshwater_molluscs/ (accessed 9 September 2020).

SousA R., ANTunes C., Guilhermino L. 2008. Ecology of the invasive Asian clam Corbicula fluminea (Müller, 1774) in aquatic ecosystems: an overview. Annales de Limnologie - International Journal of Limnology 44: 85-94. https://doi.org/10.1051/limn:2008017

ŠTAMBUK-GILJANOVIĆ N. 2003. Characteristics of water resources in Dalmatia according to established standards for drinking water. Journal of Water Supply: Research and Technology-Aqua 52: 307-318. https:// doi.org/10.2166/aqua.2003.0029

TOMOVIĆ J., ZORIĆ K., Simić V., Kostić M., KLJAJIĆ Z., LAJTNER J., PAUNOVIĆ M. 2013. The first record of the Chinese pond mussel Sinanodonta woodiana (Lea, 1834) in Montenegro. Archives of Biological Sciences 65: 1525-1533. https://doi.org/10.2298/ABS1304525T

VuČKOVIĆ N. 2013. Diversity of freshwater molluscs (Gastropoda, Bivalvia) of the Krka National Park. Diploma thesis, Faculty of Science, Department of Biology, University of Zagreb, Croatia.

ZHADIN V. I. 1952. Molyuski presnykh i solonovatykh vod SSSR. Izdatelstvo Akademii nauk SSSR, Moskva Leningrad.

Received: May 25th, 2020

Revised: September 14th, 2020

Accepted: September 28th, 2020 Published on-line: October 20th, 2020 